\title{
Study on the Causal Relationship Between China's Low Employment and Technological Progress
}

\author{
Kangshun Geng ${ }^{*}$, Haiqi Wu \\ Modern Service Economy Research Center \\ Hubei Business College \\ Wuhan, China \\ 79955004@qq.com*, 563817145@qq.com
}

\begin{abstract}
China's economy has a phenomenon of "high growth with low employment", in which technological progress will show the appearance of labor saving. There may be two causal relationships between low employment and technological progress in China. First, labor-saving technological progress has led to low employment. Second, non-technological progress has led to low employment, and low employment data make technological progress show the illusion of saving labor under the condition of rapid economic growth. Theoretical analysis shows that technological progress has two mechanisms: promoting employment and restraining employment. And the impact of technological progress on employment needs to be integrated with two mechanisms. Empirical analysis shows that the overall effect of technological progress on employment at the current stage is to promote employment, so the low employment data in China leads to the illusion of labor saving.
\end{abstract}

Keywords-Low employment; Technological progress; Influence path; Causal relationship

\section{INTRODUCTION}

Since 1978, China's GDP has grown at an annual rate of $9 \%$ [1]. Along with the rapid economic development, the employment growth rate does not match the economic growth rate in China. According to statistics, the employed people were 650 million in China in 1991, compared with 770 million in 2016. Although the employment figures show an increasing trend year by year, their growth rate is far behind the GDP growth rate. With the high speed growth of GDP, the employment growth rate shows a trend of decline. The employment growth rate was $1.15 \%$ in 1991 and only $0.196 \%$ in 2016. It fully demonstrates the reduction of jobs creation by China's economic growth.

In the course of economic growth, technological progress and employment are both arising as hot issues [2-3]. The question concerned in this paper is whether technological progress is the main cause of low employment in China. If it is, China's technological progress is labor-saving. China's economy should explore approaches to change the type of technological progress so as to promote employment. If not, then the low employment data make technological progress show the illusion of saving labor, and China should seek other means to improve the low employment problem.

\section{PROBLEM DESCRIPTION}

At present, there is a phenomenon of "high growth with low employment" in China's economy, and the demand for labor per unit output shows a downward trend. The forces that affect the change of production function besides labor and capital are regarded as technological progress, including institutional change, population structure and industrial structure. It can be considered that China's technological progress is characterized by labor saving. In economic models, this situation is usually assumed to be labor-saving technological progress. As we all know, technological progress will promote economic growth, while labor-saving technological progress will inhibit employment, and then "high growth and low employment" appears.

However, this technological progress is the residual value calculated from statistical data. It also includes factors such as demographic dividend, institutional arrangement and so on, which cannot be explained by production factors. So it is not convenient for more detailed research. The technological progress that this paper hopes to explore is the force that only makes labor productivity increase.

So the definition of this paper is as follows:

- Definition 1: Technological progress refers to the force that increases labor productivity other than productive factors such as capital and labor.

According to the empirical data of China and the technological improvement type, the research focus of this paper is on the following two opposite propositions.

- Proposition 1: in the process of China's economic development, technological progress to promote economy growth and inhibits the increase of employment, which exist labor-saving technology progress in China, it is the main cause of the phenomenon of "high growth with low employment".

- Proposition 2: in the process of China's economic development, technological progress simultaneously promotes economic growth and employment growth, and non-technological progress factors lead to low employment. Supported by the decreasing data of labor output ratio year by year, China's technological progress presents the illusion of labor saving. That is, the low employment data is the reason why the 
technical progress appearances the phenomenon of labor saving.

In order to verify proposition 1 or proposition 2 , this paper will analyses from both theoretical and empirical aspects. In the theoretical research part, it analyzes the technical progress influence on employment from micro and macro perspectives and the tracking possible results. In the empirical research part it analyzes the effect of China's technological progress on employment and the causal relationship between them.

\section{Path Of Technological Progress To Influence EMPLOYMENT}

In this part, as shown in Fig. 1, the influence of technological progress on employment is analyzed from two aspects: micro and macro perspective.

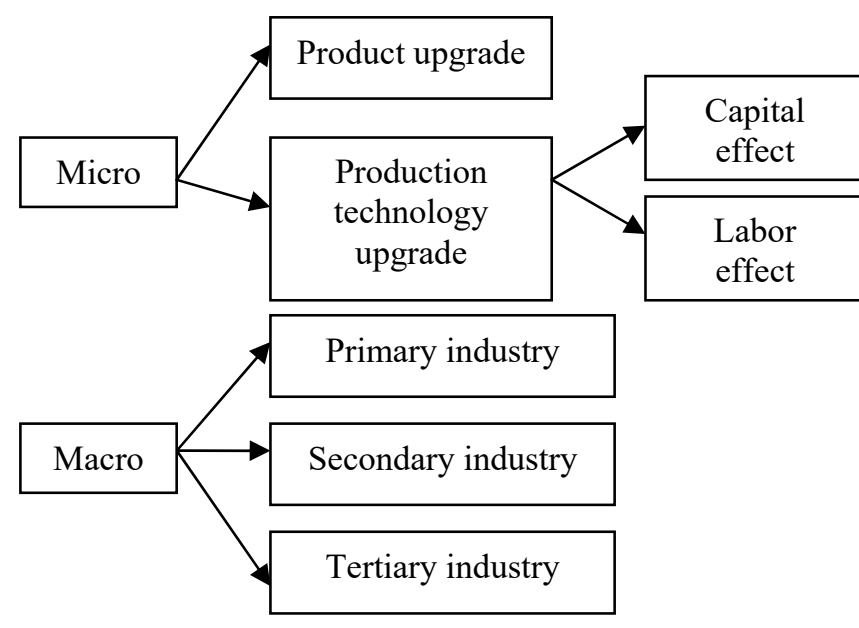

Fig. 1. Path of Technological progress to influence employment.

\section{A. Analysis of Micro Perspective}

In micro enterprise perspective, there are two means which technological progress can effect on employment, one is product upgrade, refers to through technology innovation to make advanced new products; the another one is production technology upgrade, refers to the improvement of labor productivity and the reduction of production costs, which including the upgrading of production technology of materialized and non-materialized [4].

Concretely, the mechanism of technical progress affects employment in micro perspective are:

First, the product upgrade led to the rise in employment. The specific mechanism is that product upgrading leads to longitudinal product quality upgrading and horizontal product type increase. And then the market demand for enterprise products and the enterprise's demand for labor increase. Finally, the employment rate is promoted.

Secondly, there are two factors need to be balanced among the relationship between the upgrading of production technology and employment, which is called capital effect and labor effect in this paper. From the capital effect perspective, the upgrading of production technology improves labor productivity, leads to a decline in production costs, increases the competitiveness of enterprises and increases the demand for the products of the enterprise. Therefore, the demand for labor is increased and the employment rate is rising [5]. From the labor effect perspective, the upgrading of production technology improves the production efficiency, causes the effect of "machine crowding workers", the demand for labor and the employment rate are both reduced [6].

Therefore, the impact of technological progress on employment in the micro perspective needs to be weighed two outcomes, which may lead to an increase or a decline in employment rate. Also need to consider the industry environment, financial environment, policy environment and other factors, such as whether the industry belongs to labor intensive, whether the financing conditions are strict, and whether the policy environment is loose or not..

\section{B. Analysis of Macro Perspective}

The two ways of technological progress affecting employment are different in the three industries. First of all, primary industry is full of agricultural products which are hardly being upgrade and always readily homogeneity in the market. The main way to influence the technology progress on the primary industry is the upgrading of production technology. The impact of technological progress is mainly on increasing productivity. Easily appear "machine crowd out workers" effect resulting in a decline in employment rate.

Second, the composition of the secondary industry is relatively complex, and light industry and heavy industry have different emphasis on technological progress. Product upgrading and production technology upgrading caused by technological progress are both available and need to be analyzed in combination with specific industrial sectors. Overall, employment in the secondary sector as a result of technological progress may decline or rise [7].

Thirdly, the tertiary industry mainly meets the needs of the people's spirit. Its products are mainly for service products which are not easy homogeneity in the market. The technological progress of the tertiary industry is influence on mainly embodied in the product upgrade. With the improvement of consumer demand, new service industries or service products are emerging in the market, which further increases the demand of enterprises for labor. In general, the impact of technological progress on the tertiary industry has led to an increase in employment.

The impact of technological progress on employment in three industries is described above. In addition, it is necessary to combine the population, regime, natural resources and other macroeconomic environment to make specific analysis. At the same time, the wage gap between industries caused by technological progress has prompted the labor force to make "self-selection" in the process of industrial transfer [8]. According to Engel's law, consumer demand shifts from primary to tertiary industries. Accordingly, the economic development center also presents the trend of transferring from the primary industry to the tertiary industry. China as a 
developing country, the overall effect of technological progress on employment should appear the trend of first declining and then rising.

In conclusion, both from the micro and macro aspects, the technical progress on employment have two kinds of mechanism as promote and restrain employment, the overall impact of technological progress to employment should be the result of two mechanisms.

\section{AN ECONOMETRIC MODEL}

\section{A. Basic Assumptions and Research Methods}

The above analysis researches paths in which technological progress affects employment. The results represent that the comprehensive impact of technological progress on employment may be to promote employment or to suppress employment. So, proposition 1 or 2 are both possible. Purposes of this econometric model need to demonstrate the possibilities of the proposition 1 or 2 . In the one hand, seek the causality of the low employment and technological progress; in the other hand, explain the technological progress is promoting or inhibition of employment.

The research method in this econometric model is: selecting two variables representing the technological progress and employment. Firstly, the stability of variable sequence is verified, then the co-integration analysis of variables series is carried out. Finally, two variables are tested by Granger causality test.

\section{B. Variable and Sample Selection}

- Technical progress (A): according to the definition made in this paper, labor productivity is selected as the index to measure technological progress.

- Employment (L): the total number of employed people by the whole society was selected as the index to measure employment.

In order to avoid the interference of institutional factors in the early stage of reform and opening up, the sample size selected in this paper is from 1991 to 2016. Relevant annual data were obtained and calculated based on the website database of the statistics bureau of the People's Republic of China, all data were calculated at the constant price in 1991. In order to reduce the heteroscedasticity, all data are in Log form.

\section{Variable Inspection}

1) Stability test: Through ADF test, it can be seen that L and A belong to second-order single whole sequence. As shown in Table I.

2) Co-Integration test: According to the above analysis, L and $\mathrm{A}$ belong to the same order single whole sequence and meet the necessary conditions of bivariate co-integration. The following is the use of EG two-step method for analysis.

The co-integration equation is established as follows:

$$
L=9.3732+\quad 0.2454 A
$$

The adjoint probability of the constant term and $\mathrm{A}$ are " $0.0000 "$, and the goodness-of-fit $\left(\mathrm{R}^{2}\right)$ is $72 \%$.

ADF test was conducted on residual e of the above equation, and the results are shown in Table I. It can be seen that $\mathrm{L}$ and $\mathrm{A}$ have a long-term stable co-integration relationship through co-integration test. And according to (1), their co-integration coefficient is positive.

TABLE I. ADF TEST RESULTS

\begin{tabular}{|l|l|l|l|l|}
\hline Variable & $\begin{array}{c}\text { Inspection } \\
\text { Type (c, t, } \\
\mathbf{k})\end{array}$ & $\begin{array}{c}\text { ADF } \\
\text { Testing }\end{array}$ & $\begin{array}{c}\mathbf{5 \%} \\
\text { Critical } \\
\text { Value }\end{array}$ & Test result \\
\hline L & $(\mathrm{c}, 0,1)$ & -1.86 & -3.02 & $\begin{array}{l}\text { non- } \\
\text { stationary }\end{array}$ \\
\hline $\mathrm{A}$ & $(\mathrm{c}, 0,1)$ & -1.95 & -3.02 & $\begin{array}{l}\text { non- } \\
\text { stationary }\end{array}$ \\
\hline $\mathrm{DL}$ & $(\mathrm{c}, 0,0)$ & -0.88 & -3.02 & $\begin{array}{l}\text { non- } \\
\text { stationary }\end{array}$ \\
\hline $\mathrm{DA}$ & $(\mathrm{c}, 0,0)$ & -2.24 & -3.02 & $\begin{array}{l}\text { non- } \\
\text { stationary }\end{array}$ \\
\hline $\mathrm{D}^{2} \mathrm{~L}$ & $(\mathrm{c}, 0,0)$ & -4.71 & -3.02 & stationary \\
\hline $\mathrm{D}^{2} \mathrm{~A}$ & $(\mathrm{c}, 0,0)$ & -4.52 & -3.02 & stationary \\
\hline $\mathrm{e}$ & $(0,0,1)$ & -2.27 & -1.95 & stationary \\
\hline
\end{tabular}

a. Note: DL and DA respectively represent the first-order difference values of $\mathrm{L}$ and $\mathrm{A}$, while $\mathrm{D}^{2} \mathrm{~L}$ and $\mathrm{D}^{2} \mathrm{~A}$ respectively represent the second-order difference values of $\mathrm{L}$ and $\mathrm{A}$.

3) Granger causality test: According to F-value, adjoint probability and minimum AIC value, the test lag period is 3 . The test results are shown in Table II:

TABLE II. GRANGER CAUSALITY TEST RESULTS

\begin{tabular}{|c|l|l|l|l|}
\hline $\begin{array}{c}\text { Lag } \\
\text { Perio } \\
\text { d }\end{array}$ & $\begin{array}{c}\text { Null } \\
\text { Hypothesis }\end{array}$ & $\begin{array}{c}\text { Number of } \\
\text { Observations }\end{array}$ & $\begin{array}{c}\text { F- } \\
\text { statistic }\end{array}$ & Probability \\
\hline \multirow{2}{*}{3} & $\begin{array}{l}\text { A is not the } \\
\text { Grange cause } \\
\text { of L }\end{array}$ & \multirow{2}{*}{19} & 1.7566 & 0.2088 \\
\cline { 2 - 4 } & $\begin{array}{l}\text { L is not the } \\
\text { Grange cause } \\
\text { of A }\end{array}$ & 8.5585 & 0.0026 \\
\hline
\end{tabular}

It can be seen that at the $5 \%$ confidence level, the original assumption is rejected that $\mathrm{L}$ is not the Grange cause of $\mathrm{A}$, that is, L is the Grange cause of A. Conversely, A is not the Grange cause of L.

\section{Results of Econometric Model}

The long-term stable co-integration relationship between the above indicators was tested by the EG two-step method, which eliminated the possibility of pseudo-regression. The coefficient of the bivariate co-integration equation is positive, indicating that technological progress is positively correlated with employment when other factors are ignored.

The Granger causality test results above indicate that employment is the Granger cause of technological progress, which reflects the time sequence relationship between the two data changes.

\section{CONCLUSIONS AND RESEARCH PROSPECTS}

This paper make theory analysis and empirical analysis of the relationship between China's low employment and 
technological progress, the main conclusion for the current stage of China's technological progress overall impact is to promote employment, that is, the technological progress is not the cause of the low employment in China, whereas low employment data present the illusion of labor-saving technological progress.

Theoretical analysis shows that technological progress has different ways of influencing employment. From the micro perspective, the technological progress will lead to the rise or decline of the employment rate by different ways. From the macro perspective, the impact of technological progress on the employment of the three industries is different. The result of the impact on the primary industry is biased towards the decline in the employment rate and the result of the impact on the tertiary industry is towards the increase in the employment rate. Considering Engel's law, social demand is gradually shifting to the tertiary industry. Therefore, in the process of economic development, the impact of technological progress on employment has led to the trend of rising employment rate. Specifically, technological progress has two impact mechanisms: promote employment and suppress employment. The overall impact of technological progress on employment needs to be integrated with two mechanisms.

Econometric analysis shows there is a positive correlation between China's technological progress and employment growth. That is, the overall impact of technological progress on employment at the current stage is to promote employment. Employment is the Granger cause of technological progress. Therefore, the phenomenon of "high growth with low employment" in China is not caused by Labor-saving technical progress. That is, China's technological progress is not the cause of low employment, but low employment data make China's technological progress showing a false direction of labor saving.

Excluding technological advances, the "high growth with low employment" phenomenon in China may be caused by other factors that cause the production function to move. Specific, there may be the following factors: (1) institutional factors [9]. In the short term, the reform of the employment system has resulted in a large number of unemployed. In the long term, the imperfect labor market mechanism leads to various rules that are not conducive to employment growth. (2) Industrial structure [10]. According to Engel's law, the focus of economic development will shift from primary industry and secondary industry to tertiary industry. With economic growth and the improvement of the organic composition of capital, labor surplus will occur in both the primary and secondary industries. In this process, if the tertiary industry does not have enough capacity to absorb the surplus labor, it will generate insufficient employment growth. (3) Distortion of factor prices [11]. Rising labor price and decreasing capital price lead to a process of persistent tendency of capital deepening for China's economic operation. The substitution of capital to labor is becoming more and more obvious.

Due to the limitation of length and theme, this paper cannot analyze and test the specific factors that may cause low employment. Based on the causal analysis of low employment and technological progress, the next research direction of this paper is to discuss the particular reasons of low employment in China.

\section{REFERENCES}

[1] Z.Z. Han and Z.Y. Li, "Analysis of Economic Comparison between China and the United States," The Journal of Quantitative \& Technical Economics, vol. 7, pp. 115-133. 2014.

[2] S.B. Lyu and S.W. Zhang, "Employment "polarization" in China: An Empirical Research," China Economic Quarterly, vol.2, pp. 757-778, 2015.

[3] S. Lachenmaier and H. Rottmann, "The Effect of Innovation on Employment:A Panel Analysis," International Journal of Industrial Organization, vol. 29 (2), 2011.

[4] J. Humphrey and H. Schmitz, Governance and Upgrading: Linking Industrial Cluster and Global Value Chain Research. IDS Brighton, Working paper: 2000.

[5] P. Paolo, "Technical Change and Labor Displacement: Some Comments Recent Models of Technological Unemployment," Economics of Structual and Technological Change, vol. 4, pp. 34-39, 1997.

[6] P. Aghion and P. Howitt, "Growth and Unemployment," Review of Economic Studies, vol. 61, 1994.

[7] Y. Wei and X.S. Gong, "The Progress of Science and Technology, the Upgrading of the Industrial Structure and Regional Employment Differences, "Industrial Economics Research, vol. 4, pp. 19-27, 2012.

[8] G.J. Borjas, "Self-Selection and the Earnings of Immigrants," American Economic Review, vol. 77(4), pp. 531-553, 1987.

[9] Y.J. Song, "Analysing Cause and Trend of Reform and Development about Labor System in China," Journal of Fujian Normal University, vol. 3, pp. 11-17, 2012.

[10] H. Wang, J.Y. Huang, and W. Wang, "An Empirical Study on Labor Force Supply and Demand under the Situation of Population, Industrial and Employment Structure Adjustment," Population and Economics, vol. 2, pp. 96-105, 2014.

[11] J. Wang, "Price Distortion, Biased-Technological Progress and Employment -Based on Empirical Analysis of the Panel Data of Tertiary Industry Sectors," Industrial Economics Research, vol.3, pp. 91-101, 2016. 